\title{
Penerapan Mikrotik Dalam Mengembangkan Infrastruktur Jaringan Pada Kantor Desa Rumbuk Kecamatan Sakra
}

\author{
Yupi Kuspandi Putra ${ }^{1}$, Muhamad Sadali², Mahpuz ${ }^{3}$ \\ ${ }^{1}$ Program Studi Sistem Informasi, Universitas Hamzanwadi \\ 2,3Program Studi Teknik Informatika, Universitas Hamzanwadi \\ yupi.putra@gmail.com
}

\begin{abstract}
Abstrak
Topologi jaringan yang digunakan pada kantor desa Rumbuk adalah topologi star, dimana setiap PC/komputer pada setiap ruangan dihubungkan menggunakan kabel UTP. Sementara semua handphone yang terhubung dengan wireless (tanpa kabel) melalui access point yang terdapat pada modem. Permasalahan yang terdapat pada infrastruktur jaringan ini adalah dalam pengelolaan hotspot, monitoring dan keamanan jaringan. Dari permasalahan tersebut, penulis merekomendasikan untuk melakukan pengembangan dengan menerapkan mikrotik dalam membangun infrastruktur jaringan pada kantor desa Rumbuk kecamatan Sakra. Tujuan dari penelitian ini adalah untuk membantu pemerintah desa dalam mengelola jaringan dengan melakukan monitoring, mengatur bandwidth, dan meningkatkan sistem keamanan jaringan menggunakan mikrotik. Sehingga pemerintah desa dapat meningkatkan pelayanan bagi masyarakat dalam bidang teknologi informasi secara optimal. Pengembangan topologi jaringan dan hotspot ini diperlukan untuk memberikan kemudahan bagi pemerintah desa dalam mengakses jaringan, tidak hanya jaringan kabel tetapi juga jaringan nirkabel (wireless). Dengan menerapkan mikrotik dalam infrastruktur jaringan ini untuk mengontrol semua peralatan dan pengguna jaringan yang di izinkan masuk atau tidak. Pengaturan bandwidth kepada semua pengguna jaringan disesuaikan dengan kebutuhan masing-masing. Serta sistem keamanan yang terdapat pada mikrotik sudah cukup aman, dikarenakan mikrotik dapat membatasi hak akses setiap pengguna yang masuk dalam jaringan tersebut.
\end{abstract}

Kata kunci : Topologi Jaringan, Wireless, Hotspot, Mikrotik

\begin{abstract}
The network topology used in the Rumbuk village office is a star topology, where every PC / computer in each room is connected using a UTP cable. While all mobile phones are connected wirelessly (without cable) through the access point on the modem. The problem with this network infrastructure is in managing hotspots, monitoring, and network security. From these problems, the author recommends developing by implementing a proxy in building network infrastructure at the Rumbuk village office in the Sakra sub-district. The purpose of this research is to assist the village government in managing the network by monitoring, managing bandwidth, and improving the network security system using a proxy. So that the village government can improve services for the community in the field of information technology optimally. The development of network topology and hotspots is needed to make it easy for village governments to access networks, not only wired networks but also wireless networks. By implementing proxy in this network infrastructure to control all equipment and network users who are allowed to enter or not. Bandwidth settings for all network users are tailored to their individual needs. And the security system contained in the proxy is safe enough because the proxy can limit the access rights of every user who enters the network..
\end{abstract}

Keywords: Network Topology, Wireless, Hotspot, Microtic

\section{Pendahuluan}

Perkembangan teknologi informasi pada saat ini semakin pesat seiring dengan kemajuan teknologi jaringan komputer yang ditandai dengan semakin banyaknya aktifitas masyarakat yang dilakukan secara online. Baik itu dibidang ekonomi, sosial, budaya, politik, kesehatan, militer, maupun pendidikan. Salah satu fasilitas 
yang sering disediakan bagi pengguna internet adalah hotspot. Hotspot merupakan suatu tempat yang memiliki layanan internet dengan menggunakan teknologi Wireless LAN yang dapat diakses melalui Notebook atau perangkat lainnya[1]. Untuk menerapkan jaringan wireless dengan lingkupan luas di perlukan banyak perangkat Access Point, ketika banyaknya Access Point yang dikonfigurasi oleh administrator, baik dari sisi service set identifier (SSID) frekuensi dan channel yang harus dimaintenance terus menerus[2]. Infrastruktur jaringan yang ada di kantor desa Rumbuk khususnya dalam sistem kerjanya belum optimal, dikarenakan tidak adanya perangkat yang digunakan untuk mengontrol semua pengguna yang diberikan hak akses atau tidak dalam jaringan tersebut. Selain kurangnya perangkat yang mendukung, masih kurangnya sumber daya manusia yang memiliki kemampuan dalam bidang komputer dan jaringan. Sebelumnya pemerintah desa Rumbuk sudah memiliki jaringan internet, akan tetapi sering mengalami gangguan ketika semakin banyaknya pengguna yang menggunakan internet dalam waktu yang bersamaan, sehingga menyebabkan pelayanan kepada masyarakat belum optimal. Untuk mengatasi permasalahan tersebut, pemerintah desa membutuhkan beberapa perangkat dalam membangun infrastruktur jaringan yang dapat mempermudah proses pelayanan bagi masyarakat. Salahsatu perangkat yang dibutuhkan untuk membangun infrastruktur jaringan tersebut adalah mikrotik. Hal ini sejalan dengan penelitian[1], menjelaskan bahwa pengembangan dan implementasi jaringan hotspot menggunakan router mikrotik memerlukan hardware tambahan berupa lancard, routerboard mikrotik atau PC router mikrotik, kabel UTP dan access point. MikroTik Router adalah salah satu sistem operasi yang dapat digunakan sebagai router jaringan yang handal, mencakup berbagai fitur lengkap untuk jaringan dan wireless[3]. Banyak cara untuk mengelola atau manajemen access point diantaranya dengan mengunakan controller access point system management[4], metodologi PPDIOO[5] dan menggunakan Mikrotik Router[6]. Pengembangan infrastruktur jaringan yang dilakukan dalam penelitian ini menggunakan metode Network Development Life Cycle (NDLC) dengan beberapa tahapan yaitu analisis, desain, simulasi prototipe, implementasi, monitoring dan manajemen. Penelitian ini bertujuan untuk membantu pemerintah desa dalam mengelola jaringan dengan melakukan monitoring, mengatur bandwidth, dan meningkatkan sistem keamanan jaringan menggunakan mikrotik. Sehingga penelitian ini dapat dijadikan sebagai acuan oleh pemerintah desa dalam mengembangkan infrastruktur jaringan.

\section{Tinjauan Pustaka}

\subsection{Penelitian Terkait}

Ada beberapa penelitian yang sudah dilakukan sebelumnya yang terkait dengan penelitian ini antara lain : 
Dalam penelitian[1], dengan judul Implementasi Jaringan Hotspot Dengan Menggunakan Router Mikrotik Sebagai Penunjang Pembelajaran menjelaskan bahwa pengembangan dan implementasi jaringan hotspot menggunakan router mikrotik memerlukan hardware tambahan berupa lancard, routerboard mikrotik atau PC router mikrotik, kabel UTP dan access point.

Penelitian yang dilakukan oleh[7], menyimpulkan bahwa penerapan metode PPDIOO desain LAN dan WLAN di SMK Miftahul Huda akan dapat mempermudah guru dan siswa dalam proses pembelajaran. Jaringan komputer sangat dibutuhankan untuk membantu SMK Miftahul Huda dalam melakukan efisiensi dan efektivitas dalam sistem belajar dan mengajar serta memberikan kepuasan kepada pengguna agar memiliki akses yang stabil. Pentingnya Wireless sebagai jaringan komputer nirkabel karena banyak teknologi mempunyai fasilitas wifi seperti laptop dan smartphone yang mengutamakan portabilitas dalam mengakses informasi via internet.

Pada penelitian yang dilakukan oleh[4], menjelaskan bahwa : Untuk penerapan dan implementasi Controller Access Point System Management (CAPsMAN) dibutuhkan parameter-parameter konfigurasi terlebih dahulu pada sisi router yang akan digunakan sebagai Controller access point system management (CAPsMAN) harus memiliki kemampuan wireless controller dan dari sisi access point yang akan digunakan untuk mendistribusikan wireless yang bisa disebut dengan Controller Access Point (CAP).

Dalam penelitian[8], menyatakan dengan adanya fitur keamanan serta manajeman jaringan komputer yang diterapkan seperti access control list untuk memfilter beberapa situs internet, pembagian bandwidth secara teratur untuk Pegawai dan Pimpinan, Penambahan Routerboard Mikrotik untuk mengatur jaringan local, dengan demikian maka penggunaan layanan jaringan komputer dan internet akan lebih teratur.

Berdasarkan hasil penelitian yang dilakukan oleh[9], terdapat perbandingan yang cukup signifikan pada jaringan yang belum dilakukan pengelolaan dengan jaringan yang sudah dilakukan pengelolaan menggunakan mikrotik, jaringan lebih stabil dan terkelola dengan baik. Pada sistem keamanannya tidak kalah dengan jaringan dengan biaya yang mahal, karena dengan penyetingan keamanan oleh bagian jaringan sudah cukup aman. Metode PPDIOO yang diterapkan dalam penelitian[10], menjelaskan bahwa penerapan instalasi jaringan internet wireless dengan nilai degradasi baik berdasarkan perhitungan Global Mapper, dengan kriteria kondisi geografis pada masing-masing kantor desa menuju tower BTS sebagai pemancar. Pada fase implement dengan keriteria kondisi geografis menjadi pengaruh terhadap kualitas sinyal yang didapat, baik dari sisi pemancar (Tx) maupun dari penerima (Rx). Kualitas sinyal yang didapat dan pemilihan perangkat yang digunakan akan berpengaruh 
terhadap arus data bandwidth yang berjalan. Tiap masing-masing fase memiliki peranan yang berpengaruh terhadap fase selanjutnya.

\subsection{Landasan Teori}

1. Internet

Internet adalah alat penghubung antara organisasi dan pelanggannya, sehingga tercipta sebuah organisasi baru secara virtual. internet adalah sebuah sistem komputasi di seluruh dunia yang menggunakan sarana umum untuk menghubungkan perangkat keras dan mentransmisikan informasi digital, komunitas orang dengan menggunakan sebuah teknologi komunikasi yang umum dan mendistribusikan sistem informasi secara global[11].

\section{Jaringan Komputer}

"Jaringan Komputer (computer networks) adalah himpunan interkoneksi sejumlah komputer antonomous. Dalam bahasa yang popular dapat dijelaskan bahwa jaringan komputer adalah kumpulan beberapa komputer serta perangkat yang lain seperti router, switch, dan sebagainya. Yang saling terhubung satu sama lain melalui media perantara[12].

\section{Hotspot}

Hotspot merupakan suatu tempat yang memiliki layanan internet dengan menggunakan teknologi Wireless LAN yang dapat diakses melalui Notebook atau perangkat lainnya[1].

\section{Jaringan Wireless}

Jaringan ini tidak menggunakan kabel untuk bertukar informasi/data antara komputer, sebagai gantinya digunakan gelombang elektromagnetik sebagai media transmisi data antar komputer dalam jaringan. Wireless Adapter merupakan salah satu media transmisi yang digunakan dalam teknologi Wireless Network,[8]. Wireless Access Point (W-AP) adalah secara khusus diatur simpul-simpul di jaringan Wireless Local Area Network (WLAN). Akses menunjuk bertindak sebagai satu penerima dan pemancar pusat dari WLAN sinyal-sinyal radio[13]. Access Point (AP) berperan sebagai sentral hubpada infrastruktur WLAN (Wireless LAN). AP dilengkapi dengan antena dan menyediakan koneksi tanpa kabel pada daerah tertentu yang disebut cell[14].

\section{Topologi Jaringan}

Menurut[12] "topologi dapat di artikan sebagai layout atau arsitektur atau diagram jaringan computer". Topologi meupakan

aturan bagai mana menghubungkan komputer secara fisik. Topologi berkaitan dengan cara komponen-komponen jarinagn (seperti: server workstation, router, switch) saling berkomunikasi melalui media tranmisi data. Ketika kita memilih satu topologi maka kita perlu menikuti spesifikasi yang diberlakukan atas topologi tersebut.

\section{Router}

Router adalah peralatan jaringan yang dapat menghubungkan jaringan dengan jaringan yang 
lain. Sepintas router mirip dengan bridge, namun router lebih cerdas di bandingkan bridge. Roueter bekerja menggunakan routing tabel yang disimpan di memorinya untuk membuat keputusan kemana dan bagai mana paket dikirimkan. Router dapat memutuskan rute terbaik yang akan di tempuh oleh paket data[12].

\section{Mikrotik}

Mikrotik dibuat oleh MikroTikls sebuah perusahaan di kota Riga, Latvia. Latvia adalah sebuah negara yang merupakan "pecahan" dari negara Uni Soviet dulunya atau Rusia sekarang ini. Dengan nama merek dagang Mikrotik mulai didirikan tahun 1995 yang pada awalnya ditujuka untuk perusahaan jasa layanan Internet (PJI) atau Internet Service Provider (ISP) yang melayani pelanggannya menggunakan teknologi nirkabel atau wireless. Saat ini MikroTikls memberikan layanan kepada banyak ISP nirkabel untuk layanan akses Internet dibanyak negara di dunia dan juga sangat populer di Indonesia. Mikrotik pada standar perangkat keras berbasiskan Personal Computer (PC) dikenal dengan kestabilan, kualitas kontrol dan fleksibilitas untuk berbagai jenis paket data dan penanganan proses rute atau lebih dikenal dengan istilah routing. Mikrotik yang dibuat sebagai router berbasiskan PC banyak bermanfaat untuk sebuah ISP yang ingin menjalankan beberapa aplikasi mulai dari hal yang paling ringan hingga tingkat lanjut. Contoh aplikasi yang dapat diterapkan dengan adanya Mikrotik selain routing adalah aplikasi kapasitas akses (bandwidth) manajemen, firewall, wireless access point (WiFi), backhaul link, sistem hotspot, Virtual Private Netword (VPN) server dan masih banyak lainnya[15].

\section{Metode}

\subsection{Desain Penelitian}

Metode pengembangan infrastruktur jaringan yang digunakan dalam penelitian ini adalah menggunakan metode Network Development Life Cycle (NDLC).

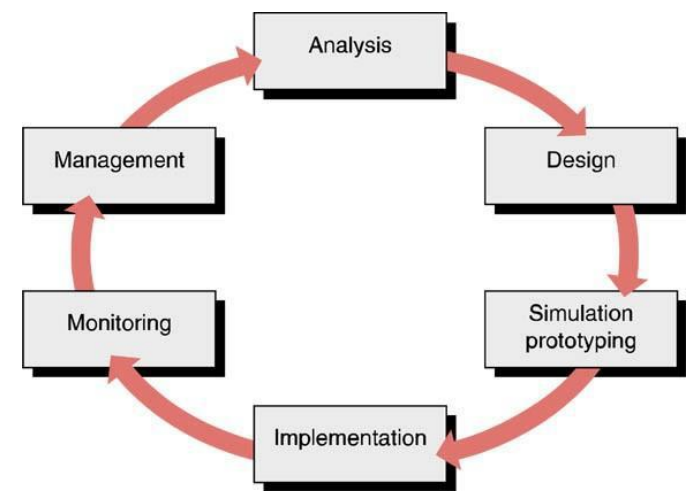

Gambar 1 Tahapan Network Development Life Cycle (NDLC).

Dalam metode Network Development Life Cycle (NDLC) terdapat beberapa tahapan sebagai berikut :

a. Analisis

Tahap awal yang dilakukan peneliti adalah menganalisis permasalahan yang muncul, kebutuhan yang diinginkan serta topologi jaringan yang sedang berjalan.

b. Desain

Berdasarkan dari hasil analisis sebelumnya peneliti akan membuat gambar desain topolgi jaringan yang akan dibangun. Dan diharapkan dapat memberikan gambaran 
yang jelas terhadap infrastruktur jaringan yang dibutuhkan.

C. Simulasi Prototipe

Pada tahapan ini peneliti membuat simulasi dengan bantuan tools khusus dalam bidang jaringan menggunakan Cisco Packet Tracert, hal ini dimaksudkan untuk melihat kinerja awal dari infrastruktur jaringan yang akan dibangun. Cisco Packet Tracert adalah software simulator jaringan yang diluncurkan oleh Cisco System yang difungsikan sebagai media pembelajaran, pelatihan, dan juga penelitian simulasi jaringan komputer[16].

d. Implementasi

Pada tahap ini peneliti menerapkan semua apa yang sudah di desain dan rencanakan sebelumnya dalam mengembangkan infrastruktur jaringan. Implementasi ini diawali dengan melakukan instalasi aplikasi winbox, konfigurasi dasar mikrotik, seperti : mengganti user dan password default, setting IP Address, Routes, DNS, Firewall, Hotspot, dan manajemen bandwidth.

e. Monitoring

Kegiatan monitoring merupakan tahapan yang sangat penting, karena admin jaringan dapat mengetahui dan mengontrol lalu lintas jaringan yang sedang berjalan secara utuh.

f. Manajemen

Pada tahapan ini dilakukan beberapa kegiatan seperti mengelola user, bandwidth, dan sistem keamanan jaringan, sehingga infrastruktur jaringan yang dibangun berjalan dengan baik sesuai harapan yang diinginkan.

\subsection{Prosedur Penelitian}

Prosedur penelitian merupakan urutan kegiatan yang harus dilalui dalam penelitian yang dilakukakn secara sistematis dengan tujuan untuk mempermudah proses penelitian. Adapun prosedur peneltian yang dilakukan oleh peneliti mulai dengan menganalisis permasalahan yang terdapat pada infrastruktur jaringan di kantor desa Rumbuk. Dari hasil analisis tersebut, lalu membuat desain topolgi jaringan yang akan dibangun. Kemudian di uji coba melalui simulasi menggunakan tools Cisco Packet Tracert. Setelah berhasil dilakukan simulasi baru diimplementasikan, serta monitoring dan manajemen.

\subsection{Sumber Data}

a. Data Primer

Sumber data yang digunakan oleh peneliti adalah hasil dari wawancara dan observasi terhadap infrastruktur jaringan pada kantor desa Rumbuk. Sehingga peneliti dapat melakukan pengembangan terhadap infrastruktur jaringan tersebut.

b. Data Sekunder

Sedangkan dalam pengumpulan data sekunder menggunakan buku, jurnal, publikasi dan lain-lain serta data yang sebelumnya pernah dibuat oleh seseorang baik di terbitkan atau tidak. 


\subsection{Instrumen Penelitian}

Menurut[17] "Instrumen penelitian adalah suatu alat yang digunakan untuk mengukur nilai variabel yang diteliti dengan tujuan menghasilkan data kuantitatif yang akurat, maka setiap instrumen harus mempunyai skala". Instrumen penelitian yang digunakan dalam penelitian ini adalah dengan mengamati langsung pada obyek penelitian serta dengan cara wawancara.

\subsection{Teknik Pengumpulan Data}

Teknik pengumpulan data dalam penelitian ini menggunakan metode observasi, wawancara dan studi literatur.

1. Oberservasi

Pengumpulan data dan infromasi dengan mengamati langsung ke kantor desa Rumbuk supaya mendapatkan gambaran yang sesungguhnya mengenai hardware dan software yang digunakan serta melakukan pengecekan ulang terhadap infrastruktur jaringannya.

2. Wawancara

Peneliti melakukan wawancara dengan sekretaris desa Rumbuk dan pengguna untuk mendapatkan data dan informasi yang berkaitan dengan penggunaan jaringan internet pada kantor desa Rumbuk.

3. Studi Literatur

Pengumpulan data dan informasi dengan membaca buku, jurnal, publikasi dan lainlain serta data yang sebelumnya pernah dibuat oleh seseorang baik di terbitkan atau tidak yang dapat digunakan sebagai acuan dalam melaksanakan penelitian.

\subsection{Teknik Analisis Data}

1. Analisis Permasalahan

Melakukan analisis terhadap permasalahan atau kendala yang dihadapi terkait dengan infrastruktur jaringan pada kantor desa Rumbuk, serta memberikan solusi terhadap masalah yang ditemukan.

2. Analisis Kebutuhan

Peneliti menganalisis kebutuhan perangkat yang diperlukan baik itu hardware maupun software dalam pengembangan terhadap infrastruktur jaringan.

3. Analisis Topologi

Peneliti akan menggambarkan topologi yang ada pada kantor desa Rumbuk, dan membuat topologi baru yang akan digunakan untuk melakukan pengembangan terhadap infrastruktur jaringan.

\subsection{Lokasi Penelitian}

Lokasi dalam penelitian ini dilakukan di kantor desa Rumbuk kecamatan Sakra kabupaten Lombok Timur.

\section{Hasil dan Pembahasan}

\subsection{Analisis}

Berdasarkan hasil analisis pada infrastruktur jaringan yang ada pada kantor desa Rumbuk, maka peneliti merekomendasikan untuk melakukan pengembangan infrastruktur jaringan dengan menggunakan mikrotik. 


\subsection{Desain}

1. Desain Topologi Jaringan Sebelumnya

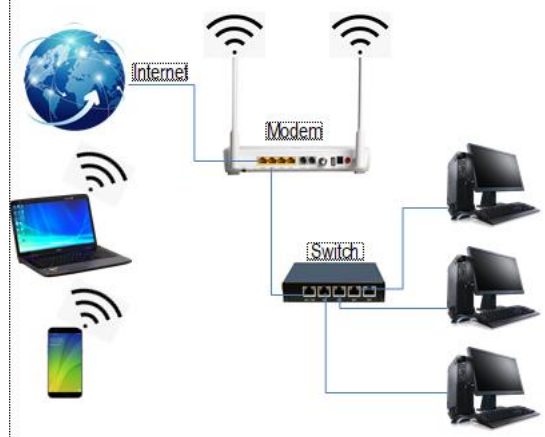

Gambar 2 Topologi Jaringan Sebelumnya

Pada gambar di atas terlihat desain topologi jaringan yang digunakan sebelumnya pada kantor desa Rumbuk adalah topologi yang masih bersifat konvensional, dimana setiap komputer pada setiap ruangan dihubungkan menggunakan kabel UTP. Sementara semua handphone yang terhubung dengan wireless (tanpa kabel) melalui access point yang terdapat pada modem. Permasalahan yang terdapat pada infrastruktur jaringan ini adalah dalam pengelolaan hotspot, monitoring dan sistem keamanan jaringan. Pada pengelolaan jaringan wireless, admin sering kali mengalami kesulitan dalam mengontrol atau memonitoring terhadap user yang sedang aktif atau tidak serta dalam pengaturan bandwidth belum bisa diberikan secara merata dan teratur kepada setiap pengguna yang terhubung dalam jaringan tersebut. Sistem keamanan yang digunakan pada jaringan ini hanya menggunakan password access point yang terdapat pada modem tersebut.
2. Topologi Jaringan Yang Diusulkan

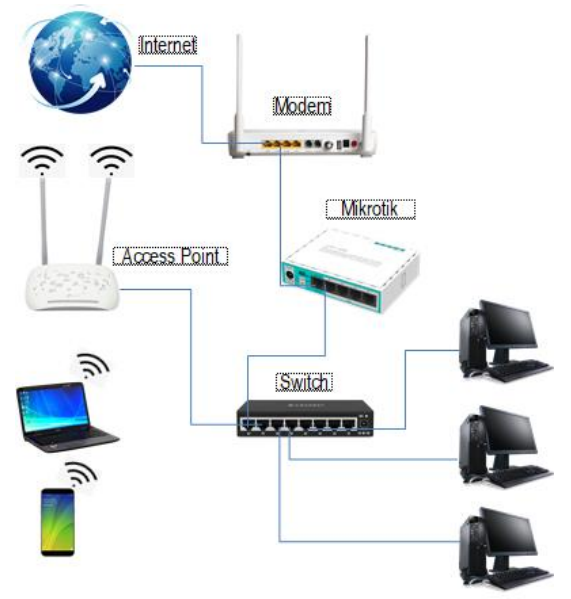

Gambar 3 Topologi Jaringan Yang Diusulkan

Gambar di atas merupakan topologi jaringan yang diusulkan dalam melakukan pengembangan infrastruktur jaringan pada kantor desa Rumbuk dengan menggunakan beberapa perangkat salahsatunya adalah mikrotik. Dengan menggunakan mikrotik admin dengan mudah memonitoring terhadap user yang sedang aktif atau tidak serta admin juga dapat membatasi bandwidth kepada setiap user sesuai dengan kebutuhan masing-masing. Yang tidak kalah pentingnya adalah sistem keamanan pada jaringan, admin dapat membatasi user yang masuk dalam jaringan bagi yang sudah terdaftar pada mikrotik atau user yang memiliki username dan password. Sehingga dapat mengurangi masalah keamanan jaringan dari orang-orang yang iseng, jahil, dan tidak bertanggungjawab.

\subsection{Simulasi Prototipe}

Dalam rancangan pengembangan infrastruktur jaringan peneliti membuat simulasi dengan bantuan aplikasi simulator dalam bidang jaringan 
yaitu menggunakan Cisco Packet Tracert, hal ini dimaksudkan untuk melihat kinerja awal dari infrastruktur jaringan yang akan dibangun. Cisco Packet Tracert adalah software simulator jaringan yang diluncurkan oleh Cisco System yang difungsikan sebagai media pembelajaran, pelatihan, dan juga penelitian simulasi jaringan komputer[16]. Dalam rancangan pengembangan infrastruktur jaringan ini peneliti menggunakan mikrotik dan access point sebagai perangkat tambahan untuk melengkapi perangkat jaringan sebelumnya.

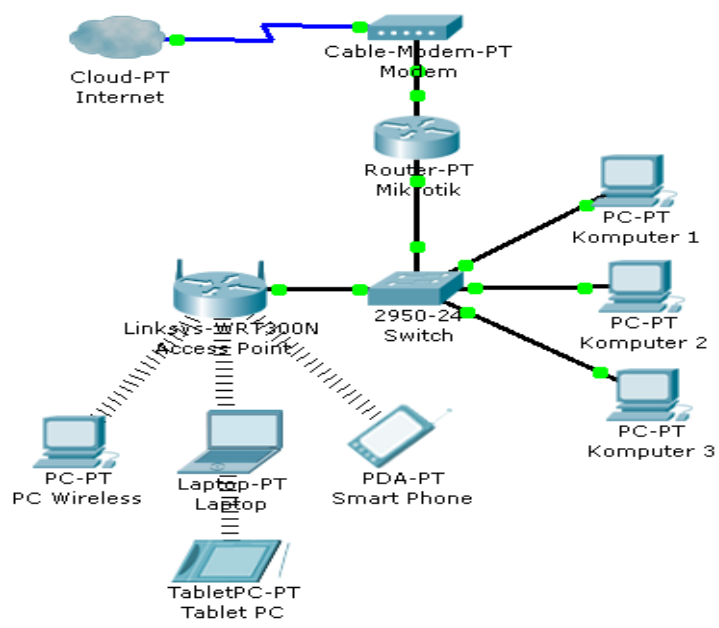

Gambar 4 Simulasi Topologi Jaringan Yang Diusulkan

\subsection{Implementasi}

1. Konfigurasi Mikrotik

Mikrotik yang digunakan dalam konfigurasi ini adalah mikrotik RB 750r2. Adapun langkahlangkah konfigurasi mikrotik sebagai berikut :

a. Login ke mikrotik menggunakan aplikasi winbox dengan mengisi username:admin dan password:kosong alias tidak perlu diisi.

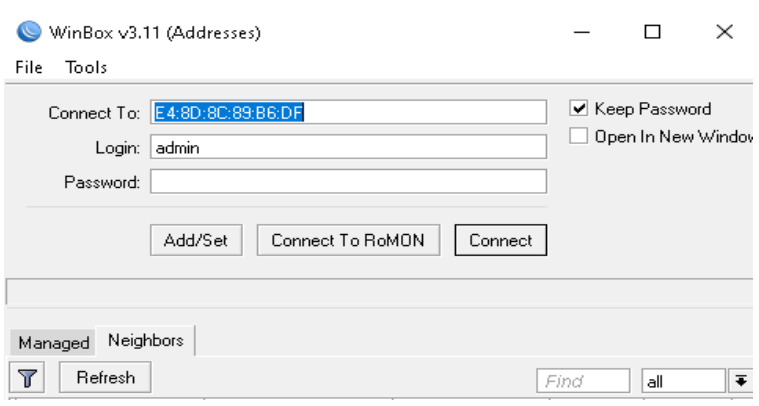

Gambar 5 Login Menggunakan Winbox

b. Membuat IP Address

Agar mendapatkan IP secara otomatis dari modem, maka buatlah eth1 menggunakan DHCP Client dengan cara klik IP > DHCP Client > pilih Tombol [+]. Membuat IP pada eth2 dengan klik IP > Addresses > pilih Tombol [+] kemudian ketik 192.168.100.1/24 seperti terlihat pada gambar berikut.

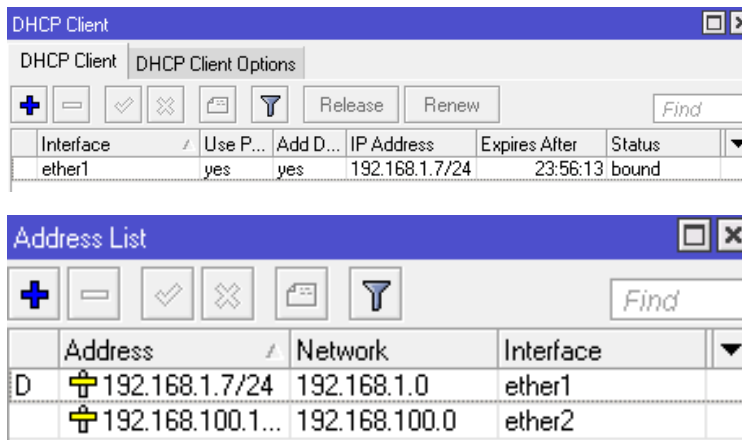

Gambar 6 Membuat IP Address

c. Setting Route

Untuk melakukan setting Route pada mikrotik pilih IP > Routes > pilih Tombol [+]. Kemudian pilih tab general ketik IP publik pada menu gateway.

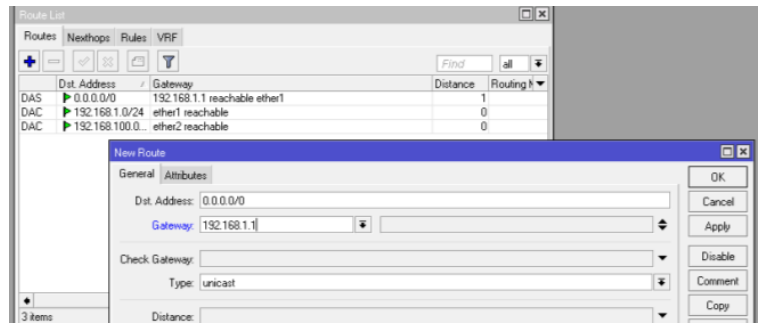

Gambar 7 Setting Route 
d. Membuat DNS

Untuk melakukan setting DNS pada mikrotik pilih IP > DNS kemudian ketik pada DNS servernya 8.8.8.8 dan 8.8.4.4 (DNS milik google).

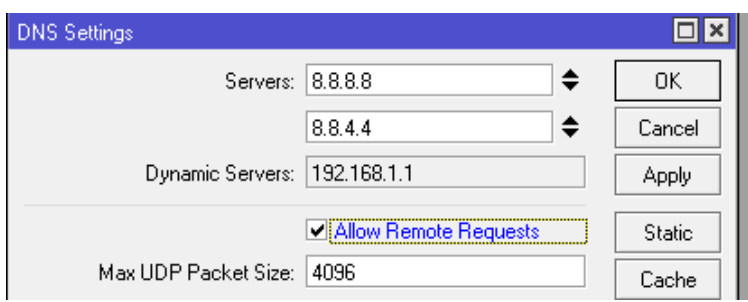

Gambar 8 Membuat DNS

e. Setting Firewall

Untuk membuar rule baru pada Firewall cukup pilih IP > Firewall > tab NAT lalu pilih Tombol [+]. Setelah muncul tampilan dari NAT baru pada tab general pilih srcnat pada menu chain lalu pada out. interface pilih ether1. Kemudian pada tab action pilih masquerade.

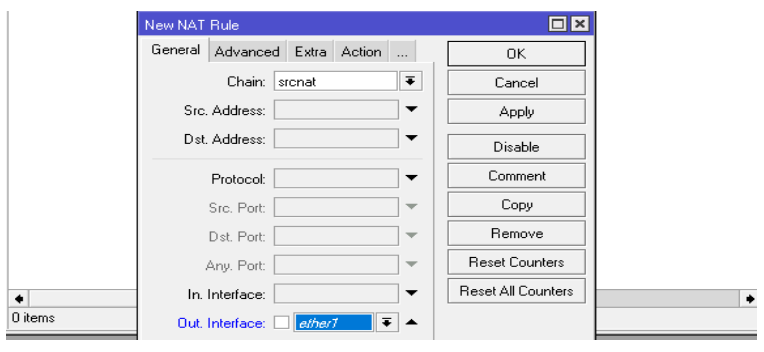

Gambar 9 Setting Firewall

f. Setting Hotspot

Untuk melakukan setting hotspot pilih IP > hotspot lalu pilih hotspot setup. Kemudian pilih ether 2 sebagai interface hotspot lalu next. Pada Local Address of Network pilih next saja, karena sudah terisi secara otomatis. Pilih next pada Address Pool of Network, lalu pilih none pada Select Certificate. Kemudian pada SMTP Server pilih next. Selanjutnya pada DNS Server isikan dengan DNS Google yaitu 8.8.8.8 dan 8.8.4.4 serta ketik pada DNS Name dengan nama kantordesarumbuk.net lalu next sampai akhirnya muncul setup has completed succsessfully dan tekan OK.

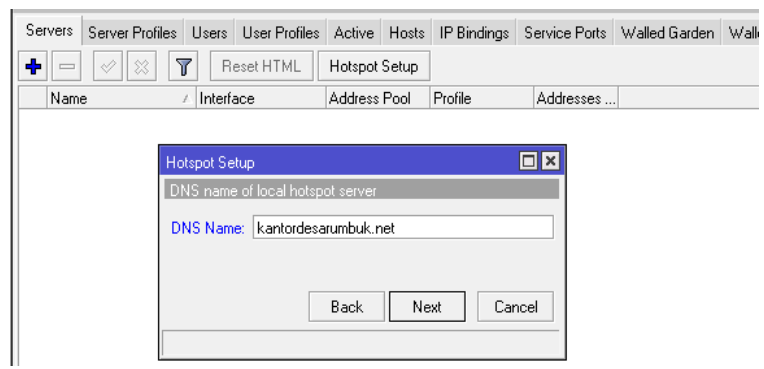

Gambar 10 Setting Hotspot

2. Konfigurasi Access Point

Pada konfigurasi kali ini menggunakan modem indihome ZTE F609 sebagai Acces Point. Berikut langkah-langkah konfigurasi modem ZTE F609 menjadi Acces Point.

a. Pastikan dalam kondisi menyala, lalu buka web browser kemudian ketik 192.168.1.1 sehingga muncul tampilan login berikut ini.

ZTE ZXHN F609

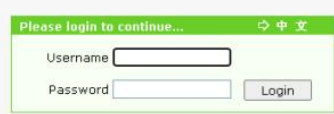

Gambar 11 Login ZTE F609

b. Setelah masuk dengan mengisi username dan password, lalu pilih network kemudian pilih menu WLAN. Seteleh itu pilih enabled pada wireless RF mode dan pada channel bisa memilih auto atau memilih salah satu channel yang sudah disediakan. Kemudian tekan tombol submit. 


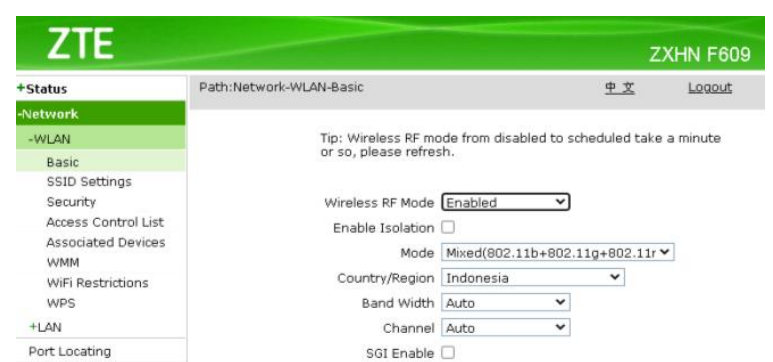

Gambar 12 Setting Wireless Mode

c. Selanjutnya masuk ke halaman SSID Setting dengan memilih SSID1. Kemudian ganti nama SSID pada SSID Name dengan nama Desa Rumbuk Hotspot, lalu tekan tombol submit.
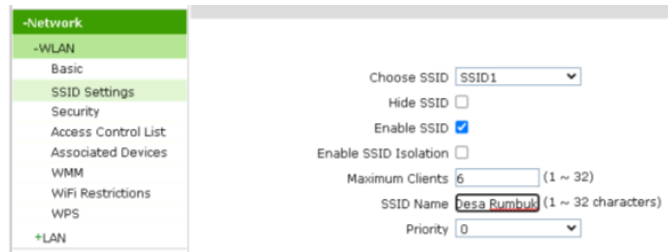

Gambar 13 Nama SSID

d. Langkah selanjutnya pada menu Security pilih Open System pada Authentication Type, lalu tekan tombol submit. Tujuannya untuk masuk ke login mikrotik ketika mendapatkan sinyal hotspot.

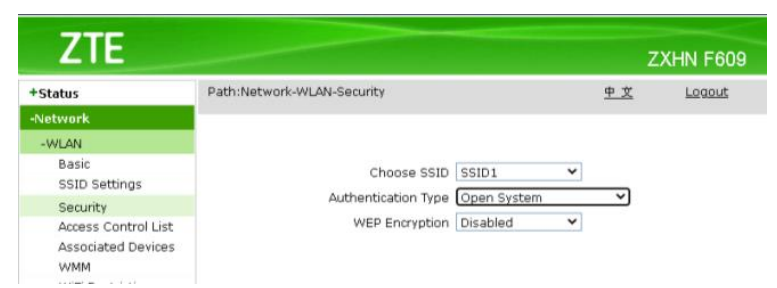

Gambar 14 Setting Security

e. Yang terakhir adalah konfigurasi IP Address dan DHCP Server. Cara mengganti IP Address dengan memilih menu LAN, lalu ganti IP pada LAN IP Address. Kemudian pada Enable DHCP Server tinggal di centang saja dan Ipnya harus satu segmen dengan IP pada LAN IP Address, lalu tekan tombol submit.

\section{Pengujian Koneksi Jaringan}

Setelah melakukan konfigurasi Mikrotik dan Access Point, maka perlu dilakukan pengujian terhadap kinerja konfigurasi mikrotik dan koneksi jaringannya. Berikut hasil pengujian dengan dua user yang sedang aktif dan dibatasi dengan bandwidth masing-masing upload $512 \mathrm{k}$ dan download $1 \mathrm{Mbps}$.

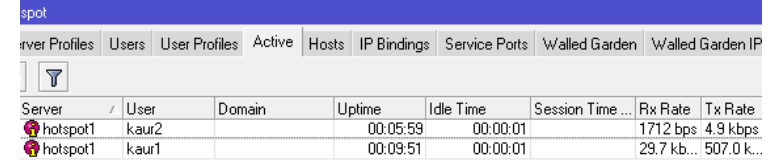

Gambar 15 User Yang Sedang Online

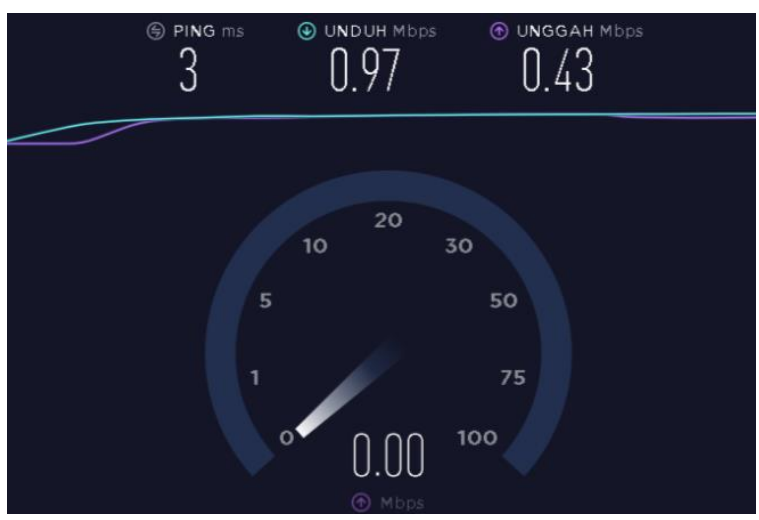

Gambar 16 Limitasi Bandwidth

\section{Kesimpulan}

Dari hasil penerapan mikrotik dalam membangun infrastruktur jaringan dapat disimpulkan bahwa dengan menggunakan mikrotik memudahkan admin untuk melakukan pengelolaan terhadap infrastruktur jaringan. Setiap pengguna di kantor desa Rumbuk yang ingin masuk dalam jaringan harus melalui login pada hotspot sehingga memudahkan admin untuk mengontrol semua pengguna yang sedang online. Dengan manajemen bandwidth pada mikrotik dapat mengurangi pemborosan bandwidth dan 
membatasi penggunaan internet di kantor desa Rumbuk, sehingga bandwidth yang didapat masing-masing pengguna cukup merata sesuai kebutuhan. Sistem keamanan yang terdapat pada mikrotik sudah terjamin keamanannya. Jadi sangat jelas perbedaan antara jaringan yang belum menggunakan mikrtoik dengan jaringan yang sudah menggunakan mikrtoik.

\section{Daftar Pustaka}

[1] Purwanto E., "Implementasi Jaringan Hotspot Dengan Menggunakan Router Mikrotik Sebagai Penunjang Pembelajaran," J. Inf. Politek. Indonusa Surakarta, vol. 1, no. 2, pp. 20-27, 2015.

[2] Towidjojo, R., \& Farhan, Router Mikrotik: Implementasi Wireless LAN Indoor. Jakarta: Jasakom, Jakarta, 2015.

[3] Riadi Imam, "Optimalisasi Keamanan Jaringan Menggunakan Pemfilteran Aplikasi Berbasis Mikrotik Pendahuluan Landasan Teori," JUSI, Univ. Ahmad Dahlan Yogyakarta, vol. 1, no. 1, pp. 7180, 2011.

[4] Rifai B. and A. Sudibyo, "Manajemen Wireless Access Point Pada Hotspot Server," PILAR Nusa Mandiri, vol. 14, no. 1, pp. 111-116, 2018.

[5] Fahlepi M. Faisal, Iswahyudi C., "Analisis Dan Perancangan Jaringan Nirkabel (Wlan) Studi Kasus Di Jogjakarta Montessori School Menggunakan Metodologi PPDIOO," JARKOM, vol. 5, no. 1, pp. 65-75, 2017.

[6] Suryanto, "Pengaturan Pemakaian Bandwidth dan Akses Jaringan Komputer Menggunakan Mikrotik Router," J. IImu Pengetah. Dan Teknol. Komput., vol. 3, no. 2, pp. 167-172, 2018.

[7] Solikin I., "Penerapan Metode PPDIOO Dalam Pengembangan LAN Dan WLAN," Teknomatika, vol. 07, no. 01, pp. 65-73, 2017, [Online]. Available: http://ojs.palcomtech.ac.id.

[8] Suwandi Ekoristio, Liow Herdy Dj.,
"Analisis Dan Perancangan Jaringan Komputer Di Dinas Komunikasi Dan Informatika Kabupaten Minahasa," Eng. Educ. J., vol. 6, no. 1, pp. 33-42, 2018.

[9] Rakhmah Syifa Nur, Kuncoro Icuk Maris, "Pengelolaan Jaringan Hotspot Menggunakan Mikrotik Router Os Pada Pt Arsen Kusuma Indonesia," J. Inkofar, vol. 1, no. 1, pp. 15-22, 2019.

[10] Umam Choirul, "Penerapan Metode Ppdioo Pada Jaringan Internet Berbasis Wireless (Studi Kasus: Kantor Desa Kabupaten Magelang)," Skripsi, pp. 1-49, 2019.

[11] Pibriana Desi and D. I. Ricoida, "Analisis pengaruh penggunaan internet terhadap minat belajar mahasiswa ( studi kasus: perguruan tinggi di Kota Palembang )," J. Jatisi, vol. 3, no. 2, p. 105, 2017.

[12] Sofana I., Membangun Jaringan Komputer Mudah membuat jaringan Komputer (W ire \& Wireless) untuk Pengguna Windows dan Linux Disertai DVD , Penerbit Informatika, Bandung. Bandung: Informatika, 2013.

[13] Kadir A. and K. Tone, "Analisa Kerja Access Point Jaringan Wireles pada Universitas Al Asyariah Mandar," J. IIm. IImu Komput., vol. 1, no. 1, pp. 1-7, 2015.

[14] Haerudin D. I., L. B. Aksara, and M. Yamin, "Implementasi Wireless Distribution System (Wds) Pada Hotspot (Studi Kasus: Smk Negeri 1 Kendari)," semanTIK, vol. 3, no. 2, pp. 105-112, 2017.

[15] Saputra R., Bandwidth Managemen Mikrotik. 2012.

[16] Ariawal D. and O. W. Purbo, Simulasi Jaringan Menggunakan Cisco Packet Tracer. Jakarta: PT. Elex Media Komputindo, 2016.

[17] Sugiyono, Metodelogi Penelitian Kuantitatif, Kualitatif Dan R\&D. Bandung: CV. ALFABETA, 2013. 